Boise State University

ScholarWorks

3-1-2011

Broker Fixed: The Racialized Social Structure and the Subjugation of Indigenous Populations in the Andes

Arthur Scarritt

Boise State University 


\title{
Broker Fixed: \\ The Racialized Social Structure and the Subjugation of Indigenous Populations in the Andes
}

\author{
Arthur Scarritt \\ Assistant Professor \\ Department of Sociology \\ Boise State University \\ Critical Sociology, v. 37 i. 1, Jan 2011
}

\begin{abstract}
Responding to calls to return racial analysis to indigenous Latin America, this article moves beyond the prejudicial attitudes of dominant groups to specify how native subordination gets perpetuated as a normal outcome of the organization of society. I argue that a naturalized system of indirect rule racially subordinates native populations through creating the position of mestizo "authoritarian intermediary." Natives must depend on these cultural brokers for their personhood, while maintaining this privileged position requires facilitating indigenous exploitation. Institutional structures combine with cultural practices to generate a vicious cycle in which increased village intermediary success increases native marginalization. This racialized social structure explains my ethnographic findings that indigenous villagers continued to support the same coterie of mestizos despite their regular and sometimes extreme acts of peculation. My findings about the primacy of race suggest new directions for research into indigenous studies, ethnic mobilizations, and the global dimensions of racial domination.
\end{abstract}

Key Words: Racialization, Peru, indigenous peoples, subjugation, colonialism, indirect rule, ethnography, race and ethnicity.

While recent studies have uncovered a sophisticated persistence in anti-indigenous racist attitudes in Latin America, racism's explanatory power remains dramatically untapped. In particular, understanding indigenous people's persistent subordination requires moving beyond the bigotry of dominant populations to focus instead on explaining the sources of durable inequality. For, despite recent mass mobilizations, indigenous populations remain "the most exploited, oppressed, and politically excluded groups in society" (Otero, 2003: 249). A recent study by the World Bank (2005) shows that in Peru (2004), for example, 63\% of indigenous households live in poverty as compared to $43 \%$ of non-indigenous households. ${ }^{1}$

Racial analyses of the 1970s and 1980s made trenchant contributions about the particular economic articulation that marginalized indigenous populations, but was criticized for being an extension of class analysis and essentializing culture (Fuenzalida, 1970; Hall, 1980; Wolpe, 1980; Wade, 1997; de la Cadena, 2000). Subsequent ethnic analyses looked directly at indigenous social interactions, providing great insight into new and powerful forms of indigenous self-representation. Yet these works frequently noted the barriers of racism without having the theoretical framework to explain them (Omi and Winant, 1994; Wade, 1997; Warren and Jackson, 2003; Postero, 2004; Sawyer, 2005; Hale, 2006). Some scholars have recently resurrected racial analyses, beginning to correct twentyfive years of near silence on the subject (Weismantel and Eisenman, 1998). These authors identify new forms of "culturalist" racism prevalent amongst dominant groups which rationalize the continued oppression of native peoples (de la Cadena, 2000; Hale, 2006). As these works have been focused on dominant groups, however, they do not address the manifestation of racism in indigenous reality. Further, because they focus on attitudes, these studies do not specify the sources of enduring racial inequality out of which these racist ideologies emerge. 
This is an author-produced, peer-reviewed version of this article. The final, definitive version of this document can be found online at Critical Sociology, published by SAGE. Copyright restrictions may apply. doi: 10.1177/0896920510378768

Given these shortcomings, a major lingering question focuses on how the everyday organization of society perpetuates indigenous racial subordination. How do the normal operations of institutions continue native marginalization? How do standard practices of resource allocation reinforce racial hierarchy? How are these manifest in natives' lives? How do they circumscribe native decision-making processes? And how do ideologies rationalize continued inequalities? In sum: what is the racialized social structure faced by indigenous peoples in Latin America and how does it maintain native marginality?

I argue that institutional structures combine with cultural practices to create a colonial-type system of indirect rule, enabling racial domination through ethnic fragmentation. Natives must depend for their personhood on local mestizo "authoritarian intermediaries" whose own privileges depend on facilitating native exploitation and alienation from the city. The institutions linking natives to the urban core focus all local power into the hands of single individuals, giving village representation an authoritarian character. At the same time, indigenous villages must access urban resources through the few local individuals who successfully demonstrate facility with the dominant mestizo culture, making local governance highly exclusive. Moreover, a major aspect of mestizo cultural display entails using rural resources to endear oneself into and bolster the urban patronage networks that allocate resources. The more intermediaries siphon village funds into an urban network, the larger the projects they can broker, and the more unaccountable they become in the village, enabling them to extract ever larger amounts of village resources. The result is a system in which closer village connections to the urban core create deeper racial divides, as mestizo intermediaries become increasingly authoritarian and native villagers become increasingly exploited.

In what follows, I detail the historical development of theories speaking to the subjugation of indigenous peoples in Latin America. The core of this article then utilizes my ethnographic data to explain how the institutional and cultural elements of the racialized social structure combine to subordinate native peoples through normal social interactions. I conclude with a summary of my findings and their implications for future research.

\section{Subjugation Explanations}

Up through the 1980s, scholars tended to regard indigenous Latin American populations as inherently in conflict with Western notions of development. While differing in their explanations, neo-Marxist, mainstream economists, and cultural anthropologists all largely associated indigenous cultures with marginalization, and enfranchisement with assimilation: overcoming oppression meant ending indigenous cultures (Rostow, 1960; Isbell, 1978; Hall, 1980; Flores-Galindo, 1987; Allen, 1988; Urrutia, 1992; Degregori, 1995). Neo-Marxists were some of the only scholars to articulate an explicitly racial analysis, explaining that racial divides created a particular economic articulation enabling an extreme form of exploitation (Quijano, 1965; Cotler, 1968; Matos Mar, 1969; Fuenzalida, 1970; Bourricaud, 1975; Young, 1976; Wolpe, 1980; Degregori, 1995). They saw racial categories as immutable and economically determined, however, leading to predictions of the preeminence of class conflict and opening them to criticism of economic reductionism and cultural essentialism (Wade, 1997, de la Cadena, 2000).

The rise of successful indigenous movements, though, forced a major rethinking in the social sciences, particularly in regard to the relation between culture and politics. Instead of viewing culture as static and unchanging, works began directly problemitizing it, recasting "culture as continually reworked understandings of the world" which guide people's actions (Warren, 1992: 205). Seen this way, "culture is an important resource [for] making a wide variety of demands to overcome political marginalization and poverty" (Warren and Jackson, 2003: 1). These insights inspired a rich development of studies on indigenous self-representation (e.g., Rappaport, 1994; 2005; Mallon, 1995; Rubin, 1997; Gould, 1999; Grandin, 2000).

As investigations into cultural politics achieved greater sophistication, the initial celebratory works gave way to theories better specifying the resources, limits, and consequences involved in this new turn (Hale, 1997). In one line of research, scholars noted the insufficiency of the ethnic paradigm to capture both the power and experience of racism, as has been noted in other parts of the world such as Canada and the United States (Omi and Winanat, 1994; Kelly, 1998; Weismantel and Eisenman, 1998; Bonilla-Silva, 1999). Racial analysis of indigenous Latin America, however, remains highly controversial because racial dialogues have been associated with eugenics, because indigenous people have long been seen as diverse ethnic groups associated with their scattered rural villages, and because some scholars see race as inapplicable to the region (Wade, 1997; Bourdieu and Wacquant, 1999; Loveman, 1999). Nevertheless, with the enduring marginalization of indigenous peoples, scholars have recently begun to apply the insights about cultural politics to the system of racialized domination. These works investigate "culturalist" 
This is an author-produced, peer-reviewed version of this article. The final, definitive version of this document can be found online at Critical Sociology, published by SAGE. Copyright restrictions may apply. doi: 10.1177/0896920510378768

racism in which inequalities are naturalized as differences between diverse populations. That is, as dominant groups newly accept indigenous cultures as legitimate (rather than inherently degenerative), they rationalize economic and political disparities as differences in cultural practices rather than reflecting historic or systemic exclusions (de la Cadeana, 2000; Hale, 2006).

\section{Racial Formation}

One route for advancing these studies entails investigating the racialized social structure: how society is organized so as to perpetuate racial disparities. Critical racial theory emphasizes that racial inequality is not so much the result of disparaging attitudes or the holdover from historical events, but an evolving political system grounded in the initial European colonial project (Omi and Winant, 1994; Goldberg, 2004; 2009; Ansell, 2006). Conquest and colonization created the current concept of race and reshaped the world around it, operating through a "logic of circular and cumulative causation," in which inequalities build further inequalities to create a durable system (Tilly, 1998; Winant, 2001). As such, race became a central defining aspect of modernity: global capitalism was built on trafficking African slaves; the nation-state depended on an uncivilized dark "other" for its coherence; and Enlightenment ideas championed and even scientifically "proved" wealthy European males inherently superior to all others (Winant, 2001). This established a global system of European male privilege predicated upon the subordination of darker peoples, leading to the naturalization of a de facto "two-tiered, morally partitioned population divided between white persons and nonwhite subpersons" (Mills, 1998: 108).

These works emphasize that, once racialized, the "normal" organization and practices of society perpetuate racial subordination, engendering racial contestation while simultaneously rendering it largely invisible (Bonilla-Silva, 1997). Rather than a discreet variable, race permeates all aspects of society so that the "mundane features of the social world that at first sight do not appear to be racialized but, when analysed within an inductive, theoretical framework, are found to be directly and indirectly relevant to the construction of race as a social phenomenon" (Holdaway, 1997: 396). Racism, rather than an aberration or an individual psychological disturbance, largely entails perpetuating the system of inequality. The system ensnares the individuals it produces into perpetuating racial inequality through their everyday actions. While troubling for well-meaning whites, this dynamic creates serious dilemmas for minorities who, in some way or another, must participate in their own subordination (Collins, 1996). Overall, then, understanding durable racial inequalities requires investigating how the interacting structures and everyday practices of society generate a historically emergent racialized social structure (Bonilla-Silva, 2001: 48).

\section{Method}

As in many other areas of Latin America, the politics of highland Peru have long been characterized by a stark divide between the indigenous countryside and the mestizo or white city, with rural mestizos recognized as nonindigenous vecinos notables enjoying heightened privileges and prestige. The rural villages most closely associated with indigenous reality owe much of their current shape to the 1969 Land Reform. This abolished the hacienda system and replaced it with the "Peasant Community" system of smallholders enjoying protections against taxation and expropriation. Both of the villages I worked with could access the main city, Ayacucho (twelve and sixty kilometers away), through public transportation on serpentine, vertiginous and poorly maintained narrow dirt roads typical of the contemporary Andes, and regularly did because this was the hub of economic and political activity. Villagers therefore did not overly suffer from geographic isolation; but the ability to visit the city did not readily translate into access to its institutions.

Both villages sat in small valleys ringed by steep hillsides covered in patchwork fields. Small adobe houses hunched around a main square, host of the community house (casa comunal). Pre-industrial quiet reigned, with cars and busses infrequently passing through one village and almost never visiting the other. Residents primarily spoke Quechua, the indigenous language spread by the Incan Empire. Reproductive strategies, as in most parts of the rural Andes, consisted of a combination of farming off of scattered land parcels and paid labor (mostly at US\$3.50 per day), either in the immediate area, in the city, or through temporary migration. Long-standing integrated agropastoralism filled most days, with local rules governing when cows could enter fields to glean and fertilize.

Villagers practiced several forms of mutual labor exchange, predominantly the faeana, in which all families worked on village projects (such as cleaning irrigation canals), and the ayni, where some mutuality (including limited paid labor) regulated groups working in fields controlled by individuals. Communities generally governed themselves, 
This is an author-produced, peer-reviewed version of this article. The final, definitive version of this document can be found online at Critical Sociology, published by SAGE. Copyright restrictions may apply. doi: 10.1177/0896920510378768

periodically electing a presidential junta, though were also connected to a district mayor and district governor, with villagers serving as representatives of each system, and with no civic funding guaranteed from any of the bureaucracies. The terrible violence of the 1980 s civil war touched but did not radically alter both villages, pushing many villagers to spend more time in the city and commute to their lands.

As I began my research, I came to realize that the political contours of the communities centered on the perennial village leaders. These men dominated village policies at all levels. More mysteriously, villagers regularly denounced them for malfeasance, yet continued to entrust them with policy decisions, labor, and money. Explaining their power became the obvious focus of my work. Where does it come from? How is it so extreme? Why did villagers continually support them despite open acts of corruption? And, perhaps most importantly, how does it speak to the integration of indigenous populations into national and global society?

To understand this, I cast my net widely, attempting to interview as broad a spectrum of villagers as possible as well as representatives from most of the primary agencies that served the communities. After nearly two years of research in 1999-2000 and again in 2002-3, I became a yerno (adopted son) of both villages, collected over 150 interviews which were either taped and transcribed or written up after they were conducted, and complemented these by a review of extant village archival materials. The strength of my data lies in the richness of their testimonies about village events from which I was able to construct a thick description of the past twenty years of village governance. While men were only a slim majority of my respondents $(<60 \%)$, politics remains a male purview causing a possible gendered slant to my data. Further, the village-centric collection method and primary reliance on respondents' memories threaten further distortions. Triangulating from rich multiple perspectives, however, provides one of the best routes for interpreting complex village events and dampening biases of personal situations or motivation. Nevertheless, a more intimate investigation of the interface of villagers with urban institutions and a deeper exploration of archival resources (in urban institutions) could add accuracy to the data. All in all, though, my research pointed to an inordinate concentration of power among a select group of men, which, I will argue, was facilitated by the racialization of highland Peruvian society.

\section{The Peruvian Racialized Social Structure}

So what does the Peruvian racialized social system consist of and how does it subordinate native peoples? In exploring this question, my work continues the tradition of investigating the "Indian Question" or "Native Problem," namely: how does a small minority of European descent dominate a larger and potentially hostile indigenous population? Mamdani $(1996$; 1998) presents one of the most theoretically sophisticated treatment of the systemic domination of native peoples. He explains that colonial leaders answered the Native Question throughout much of sub-Saharan Africa through a system of "indirect rule," generically epitomized by Apartheid.

In this system, the native populations were differentiated and segregated from each other and ruled through "native" institutions based on ostensibly traditional or customary practices and laws, but created and maintained by the power of the central state. The white urban rulers created and supported their rural "tribal" proxies who served both as the principal conduit between the countryside and the urban power centers, and in whom was fused "all moments of power: judicial, legislative, executive, and administrative" (Mamdani, 1996: 23). While "the customary was more often than not the site of struggle,... the terms of the contest, its institutional framework, were heavily skewed in favor of state appointed customary authorities" (Mamdani, 1996: 22). The racialized state attempted as much as possible to divide the white town from the black country, and splinter the rural areas into multiple competing ethnic enclaves. As Mamdani says, "Racial dualism was thereby anchored in a politically enforced ethnic pluralism," with this dualistic colonial legacy reproduced up through today in a structure of "decentralized despotism" (1996: 7).

\section{Historical System Construction}

The Peruvian system parallels the African but with key differences due to its longer colonial history. Spanish colonialism racialized the natives in order to exploit them, classifying them ideologically and institutionally as inherently inferior beings. This ushered in draconian policies which decimated the population through degrading living and working conditions and cycles of genocidal violence (Wolf, 1982; Klarén, 2000; Postero, 2006). But a simultaneous re-ethnicization splintered regional populations into highly localized identities based on the European authorities who provided the only, albeit highly paternalistic, protection in this exploitative system. Racial domination thereby occurred through ethnic fracturing, the state ruling over native areas "on the cheap" by granting 
This is an author-produced, peer-reviewed version of this article. The final, definitive version of this document can be found online at Critical Sociology, published by SAGE. Copyright restrictions may apply. doi: 10.1177/0896920510378768

carte blanche to local authoritarian figures who reciprocated by providing rural quiescence. These local state proxies have had various names throughout history, including encomendero, subdelegado, gamonal, caudillo, tinterio, and hacendado.

Patronage has long fueled this Peruvian variety of racialized rule. The Crown had to control a huge new territory and population dwarfing its home domain. Racialized patronage enabled it to do so. Spanish settlers enjoyed the unique rights granted only to the "civilized" people of Europe, as established in the Régimen de Castas and other laws enforcing the racial hierarchy (Morner, 1965). Lavishing rewards upon these citizens, including land tracts larger than many current US states, ensured a continual flow of goods and labor from the "primitives" in need of Enlightened European guidance (Klarén, 2000). As their sole link to the outside world, native wellbeing depended upon the success and beneficence of their local patron. The system thereby forced natives to provide tributes to the extremely powerful local individual whose own position depended upon continuing native fragmentation. Moreover, this extreme form of paternalism heavily enforced the racial hierarchy by forcing the native "sub-persons" to depend almost exclusively on their local European citizen without the possibility of ever achieving this personhood themselves (cf. Mills, 1998).

The preeminence of paternalist exchanges has thereby long enabled racialized governance. This system dominates through providing rather than denying resources. And it does so in order to enable an efficient if cruel means of control - rather than other ostensible goals such as saving souls, personal fulfillment, or raising standards of living. Further, the state structure made paternalist racialization the easiest path to follow - any deviation requiring tremendous effort - ensuring the continuation of racial inequality.

State policies have reproduced this racialized authoritarian model as an explicit part of the major transitions since colonialism - Independence, nation-state formation, land reform, developmentalism, and globalization - the topic of another paper (cf, Mallon, 1995; Thurner, 1996). As van den Berghe and Primov (1977) found for rural areas in the 1970s:

The mechanisms for maintaining inequality are so solidly entrenched and so thoroughly routinized that unequal relations take place under a veneer of benevolent despotism on the part of the dominant group and ingratiating subservience on the part of the dominated group. (127-30)

For my purposes here, it is important to note that while these historic disruptions presented major opportunities to shift to more inclusive models, the regular outcomes retrenched decentralized despotism through providing it with new resources and innovations. Further, as the above quote indicates, these exploitative relations have become thoroughly naturalized, understood as a normal aspect of daily relations and therefore not fully necessitating coercive enforcement.

Two important and intertwining changes have altered this system without changing its overall authoritarian form. Throughout twentieth century Latin America, governments and societies variously turned from ideas of inherent racial superiority towards an all inclusive model of the mestizo "Cosmic Race" - a sui generis people emerging from the union of natives and Europeans (Vasconcelos, [1925] 1979). Mestizaje (becoming mestizo) newly promised universal citizenship through a celebration of the native heritages of the Americas - though only as a mix with European stock. As it strove for inclusivity, then, state mestizaje simultaneously renovated racism, delivering "a double blow, denigrating the unassimilated while inciting the assimilated to wage an endless struggle against the 'Indian within'” (Hale, 2004: 17). Citizenship became more inclusive, but only through creating a new sector whose rights depended upon continually proving their deservingness by denigrating natives.

Soon after mid-century, mestizaje became interwoven with the emerging "developmentalist" ideas of progress through industrialization spearheaded by an interventionist state. The governments not only promoted a specific capitalist agenda, they tied it seamlessly to novel assimilationist policies. This was evidenced most obviously when states, responding to rural discontent, turned "natives" into "peasants" with a quick slash of their pens. While promising greater enfranchisement, these reforms traded native patrimonial rights for the class rights to work the soil, effectively divorcing any local victories from demands for larger changes to the system of racialized rule. At 
the same time, state mestizaje created a new middle stratum that personified the developmentalist progress that promised to transcend the old governing ideas of racial degeneration. This group carried a powerful authority regarding modern progress. "Developing" meant becoming mestizo. Thus the contrast with indigenous peoples only became sharper, natives now denigrated as anti-modern barriers to economic advancement.

\section{The Current System}

The current structure has inherited the key facets of its historical antecedents, though has altered and revitalized them in important ways. Figure 1 sketches the workings of this system. The bold outlined boxes denote the key racial positions and their roles in governing the racial hierarchy. Patronage connects the groups, cycling from the most privileged groups to eventually reach natives, and generating the loyalty that makes the upward connections.

\section{[FIGURE ONE ABOUT HERE]}

The principal end goal entails central authorities achieving native acquiescence. But this is an indirect outcome achieved through proxies. The crucial relations achieving this objective occur around the position of mestizo broker, and are therefore the central focus of this article. These relations push brokers to exploit and rule despotically over their indigenous wards, amounting to a revitalized form of indirect rule I call "authoritarian intermediation." The normal structures and practices of the institutions linking villages to the city concentrate all local power into the broker position, predicating this privileged position upon fulfilling urban priorities of a tractable rural clientele. And complex, fluid, and historically emergent cultural understandings ensure that only a select few individuals who can most convincingly demonstrate their mestizo credentials will operate as brokers. In all, the institutional forms and cultural practices combine to make the rural-urban link as narrow as possible, thereby vesting all local power in the few individuals who can bridge this divide, and predicating their privileged position on continuing the historic flow of native resources into urban power centers.

More specifically, the system creates a self-reinforcing "Exploitation-Authority Cycle" (Figure 2) in which greater broker success causes their native wards to become increasingly politically dependent and economically exploited. Natives must access external resources through the few local individuals who are willing and able to act according to mestizo urban cultural norms. As indicated in figure two, however, accessing urban projects entails providing urban functionaries with rural resources, itself a display of mestizo cultural wherewithal. This tribute endears brokers to urban patrons, enhancing the personalistic relationships through which patronage networks distribute funds. As broker-functionary relations build, programs can grow in complexity and duration. Spearheading larger and multiple projects enhances broker authority in the village, increasing their local impunity and legitimacy.

\section{[FIGURE TWO ABOUT HERE]}

The larger and more involved a program, the more funds brokers can take from villagers, and the more they can keep delaying the eventual payoff. As program acquisition requires community subsidization, intertwining simultaneous programs helps obscure the source, destiny, and eventual results of funds, increasing villager dependence as resources increasingly circulate out of their hands. Like an authoritarian Ponzi scheme dictating that "investors" never withdraw their money but keep it cycling within the system, brokers can gain control over tremendous sums - relative to the impoverished Peruvian highlands - over which they enjoy ever increasing impunity. Villagers, meanwhile, become increasingly dependent on and exercise less restraint over the brokers. Villager options consist of acquiescing to demands for more contributions in the hopes of recovering what they have already given, or withdrawing with the consequences of writing off their losses and shearing their connections to the urban core. These relations can spiral to fantastic levels of peculation after which withdrawal becomes the majority decision; but this breaking point has proven dramatically high. The remainder of this article elaborates the system empirically.

\section{On the Ground}

Villagers in both communities I investigated regularly decried that "the local government has always embezzled [community] funds, without really showing anything for it." Indeed, even most of the individuals who dominated these offices believed people (themselves excluded) only served for their own personal gain, generally insinuating some kind of overt corruption. In both villages, presidents and their cronies regularly profited from acquiring or 
selling-off village resources, such as communal lands, stands of eucalyptus trees, and cochineal. Additionally, as in most of the countryside, unfinished infrastructural projects littering both communities testified to village leader kickbacks, inspiring villagers to condemn projects as initiated "only for stealing money." Yet despite this dissatisfaction, one coterie of villagers continually dominated each community, openly profiting from their high positions. And the majority of villagers continued to participate in these broker-led projects.

Brokers were generally villagers who came from privileged positions, having gained favor from the former hacendados by serving the central jobs of yanacuna, caporal, or having tight fictive kin relations. Many further differentiated themselves through using their privileges to acquire urban experiences, including education and employment, and an overall apprenticeship in the dominant culture. Researchers have frequently rejected racial analyses because phenotype plays little role, as indicated here by the fact that mestizo brokers and indigenous community members can belong to the same family (van den Berghe and Primov, 1977; Albó, 1994: 194; Wade, 1997). As I will show, though, the intense rural-urban division and racialization of state resources means that native Quechua speakers with superior urban experiences can recreate themselves as mestizo in order to gain tremendous power in the village. In addition to distinguishing themselves through local privileges, however, brokers were the individuals who were also willing and able to "prove" their mestizo qualities by, among other things, assenting to do the bidding of urban functionaries interested in enlarging their networks of patronage (many of whom were former hacendados). A series of events in one village, Huaytabamba, demonstrates the dynamics at play.

In the mid 1980s, the former hacendado of what had become Huaytabamba told village brokers that the community actually owned almost two hundred hectares of land which the neighboring village currently controlled and had historically worked. Marshalling community resources, the brokers sued for the territory, winning a judgment but never acquiring the land because of the other village's unwillingness to accede. In one episode, Huaytabamba paid the police to enforce the court order; but the gendarmes quickly quit the field in the face of rock-wielding opponents, leaving the villagers alone to retreat bruised, without the land, and poorer.

Through this experience village intermediaries learned that they could wield tremendous influence over community funds and actions, with their demonstration of urban knowledge and large promises generating unquestioned contributions even when no product was delivered. And urban institutions proved incredibly eager to leave rural governance in broker hands. To use Mamdani's terms, the brokers came to fully realize that the village was not governed by "modern" law but by "traditional" law which the brokers themselves could dictate with near impunity at least within their own village.

At this time, central authorities and the reigning political party, Acción Popular, sought political loyalty through farming out infrastructural projects (Klarén, 2000). So, the village intermediaries brokered many state sponsored programs, delivering on some projects but leaving many unfinished - and profiting on them all. These relations were enhanced through a partnership with an official of the government development agency SierraCentroSur who directed more programs towards the community seeing that the brokers were willing and able to siphon most of these funds back into the partnership. In a larger plan in the late 1980s, brokers acquired sizable low interest loans for villagers from the new Agrarian Bank, but took half of the monies for themselves, erroneously claiming the need to pay fees. Today, some brokers still make labyrinthine arguments that villagers owe them back payments, even though the state condemned these loans long ago. As one man described the period:

at this time there was a lot of misappropriation of funds, as much from the community [coffers] as the public works.... At that time the community was used by the solicitors of works and the authorities who extracted money through faenas [communal work parties].

In addition to having villagers pay for two additional lawsuits, brokers entangled these convoluted long-term projects with a third "Cattle Reactivation" project which promised to upgrade and triple villagers' cattle holdings by selling the cattle acquired through the earlier loans. One unwitting participant explained that in the mid 1990s the lead broker

had gathered the entire community one Saturday and they had told them that the [Cattle] Reactivation had already come out and that it is going to get here the day after tomorrow. The only thing still pending was some money to give the engineers their part. He convinced the people and told them that each person would get four bulls and money according to the quantity of money they gave. This is why they sold their horses, 
cows, pigs, everything in order to supply money and have [the project] finally come out. The next day which was a Sunday [the day of the livestock market] they took all their animals to the market to sell. All of this money, up through right now, has not appeared.

Villagers entrusted the majority of their capital to this broker so he could use his urban knowledge, including bribing "engineers," to gain resources for the village. According to a wide variety of villagers, however, he just "put the money in his pocket; he stole the money" and thereby "stripped all the community members of their money." Thus, even though brokers openly profited from the projects they accessed, most of which never provided the promised services, villagers here, as well as in the other community, continued to follow brokers' mandates and provide them with funds. The following sections explain this exploitative situation.

\section{Institutional Racialization}

To alleviate indigenous poverty levels, the World Bank (2005) suggests increasing education and health funding. The new social service programs of the 1990s, however, respectively spent 50\% and 25\% of their $\$ 141$ million annual expenditures on precisely these two items, and poverty rates actually increased (Gonzales de Olarte, 1998: 62). Pace the World Bank, I found that indigenous marginalization in highland Peru is not so much the result of being left out as the particular way natives are incorporated.

Highland communities predominantly access the urban power center through what is called the solicitor [gestor] system. This distinctly "native" system links the village institutions to urban organizations, forming the backbone of racialized indirect rule. Solicitors gain all power over the resources they broker, predicated upon using these to further endear themselves into urban patronage networks. As such, rather than fulfilling rural needs, the system bolsters urban patronage networks through maintaining a compliant rural clientele. This governing structure descends from the notoriously corrupt and rapacious colonial town councils called "cabildos" (a term still sometimes used in villages) through which Europeans concentrated all local power in order to dominate the native populations (Klarén, 2000).

The fuel for the solicitor system originates in state or international organizations making resources available for rural areas. Funds pass to agents in the relevant highland cities - in this case Ayacucho - who generally either work as poorly paid functionaries in government institutions like the Ministry of Agriculture, or for an internationally funded non-governmental organizations (NGOs) like CARE, World Vision, or ADRA (Adventist Development and Relief Agency). To pass through the native color line and reach rural villages, these resources must engage the main engine of the solicitor system, therein institutionally segregating highland villages by making them governed through the distinctly "native" yet authoritarian system inherent to indirect rule.

Urban service programs work with single village representative in whom they vest all local control. When ADRA was planning its latest projects, for instance, the organization's official only negotiated with one man - who also served as an Evangelical pastor and had regularly occupied the office of president and sub-mayor. In a small dimly lit room, these two men quietly decided how to spend the organization's money and how the villagers would contribute their labor to the program. In a much larger example, the Agrarian Bank, above, entrusted all village loans to a single individual who lacked collateral and accountability, resulting in this man taking over half the funds and the government writing off most of the loans as it did across the country.

In sync with urban institutions, villagers expect that only one of their members will seek, locate, arrange, and administer resources from the city. The solicitor system is engrained in village political practices through the regularly elected community president whose chief role is to solicit projects for the village. This is the ethnic heart of the village, with community membership assuming compliance to the presidents and their projects. Similarly, the only accountability over the president consists of ethnically-based calls to safeguard villagers "like his children," and a fiscal or prosecutor elected as part of the governing junta who has never, in either village, fulfilled the office obligations of filing charges for presidential malfeasance. Fiscals lack motivation to fulfill office responsibilities as they are elected in concert - rather than in conflict - with their presidents. Herein the corrupt legacy of the cabildo makes itself highly visible, the only "oversight" actually functioning to help concentrate presidential power. 
This is an author-produced, peer-reviewed version of this article. The final, definitive version of this document can be found online at Critical Sociology, published by SAGE. Copyright restrictions may apply. doi: 10.1177/0896920510378768

The institutions of the solicitor system, then, establish a framework in which single village representatives exercise exclusive power over the resources they broker, personifying the extremely narrow bottleneck linking the village to the city. The same few individuals regularly served in this role, wearing many hats, and dominating every program. While these are generally the most experienced and successful villagers, marking them in some way as "natural" leaders, their domination has more to do with their personalistic relationships to urban power holders and their ability to cater to the demands of the clientelistic means of service delivery.

Just as local ethnic ideologies help provide unquestioning support to solicitors, they also bolster the system's extreme clientelism that makes rural-urban relations particularly exploitative. In particular, the current ethnic construction of community government equates "autonomy" with lacking any direct institutional connections. These echo the anti-exploitation Agrarian Reform rhetoric, but generally reflect elite assertions to determine local policy. Practically speaking, though, this means that community presidents are not plugged in to a larger political infrastructure which confers entitlements based on need, merit, or coherent policy goals.

While governments at other levels (department, province, and municipality) enjoy specific budgets tied to the federal government, no parallel exists for community government. Instead, presidents must go hat in hand to urban offices to beg resources, making native resource delivery highly personalistic and paternalistic in character. ${ }^{2}$ Local ethnic constructions of community "autonomy" buoy this structural isolation, equating formal institutional connections with "outside" interference. At the same time, though, villagers widely recognize that they must establish clientelistic relations with urban power holders in order to acquire external resources. As such, villagers are frequently prepared to pay various subsidies, such as dedicating crops to urban functionaries, offering free labor, supporting political candidates, or simply providing money in order to get in their good graces.

As one man described his village's relation with an urban official: "we took photos together, we thanked him by slaughtering pigs. We received him by smothering him with all kinds of attention; when he complied with his word we gave him this affection." In other words, while the urban official was simply doing his job of delivering programs to rural communities, the villagers knew they had to reciprocate with an outsized response in hopes of acquiring future projects. Corruption is pervasive in Peru, with surveys showing that the population overwhelmingly believes it is heavily entrenched and "that impunity is the rule in Peru, not the exception" (Rotta and Narvarte, 2006: 224; Transparency International, 2006). The reliance on personalistic ties in an atmosphere of overt corruption sets up a dynamic in which villagers and city functionaries expect that kickbacks are a regular facet of service delivery. Urban power holders will not deliver unless they get something in return.

Other institutional facets of the community further enable the extraction of subsidies. The solicitor model in and of itself requires villagers to make contributions towards program acquisition, as demonstrated above by people willingly selling their animals to provide kickbacks to the urban "engineers." Further, the faena system of communal work parties poises villagers to launch immediately into the physical labor requirements of the programs, including the work necessary to maintain personalistic networks, such as painting patrons' houses or dedicating an entire crop to them. Most faenas are totally unfunded projects functioning economically as a tax on locals to help maintain their village infrastructure. The faena system emerges from a strong and diffuse local ethnic ideology of community much more widely shared and incorporated into life strategies than the more elite ideology of autonomy, one man explaining to me that "without faena we are nothing, we are not a community."

The injection of external resources into this work system relieves individual burdens acquired through faena mandates, predisposing villagers to embrace whatever funds enter the system and make their labor available to the given project. External projects thereby become easily and quickly incorporated into the community system. Village elite can frequently buy themselves out of community labor responsibilities or simply work as project administrators, further distinguishing themselves from the masses (cf. Gose, 1994). So primed are all the other villagers by this system, however, they are generally at a loss to explain their participation in any complex way, instead seeing it simply as normal: "when there is something, we are all there" one man explained to me. The ethnically bound faena system thereby tends to reinforce local ethnic identification. At the same time, however, it presents brokers and other urban officials with a ready and tractable labor force generally eager to fulfill even overtly corrupt schemes. The ethnically generated workforce, then, provides the means to enact strategies emanating from the mestizo urban center, that is, to fulfill a highly racialized agenda. 
This is an author-produced, peer-reviewed version of this article. The final, definitive version of this document can be found online at Critical Sociology, published by SAGE. Copyright restrictions may apply. doi: 10.1177/0896920510378768

The villagers have little recourse against such exploitation. Even with few results, people continually gave to the above projects. While the leading broker, in his direct partnership with an urban functionary, extolled grand promises and complex explanations of future windfalls, the money was forever circling out of the villagers' hands, justified partially by the delivery of small amounts of programs from which the brokers profited disproportionately. As recounted by this broker's brother (indicating that family provides little insulation from exploitation):

The people trusted now that they did not want to lose the money they had given previously. So we were going to recover our money if the engineer was here [working on small projects]. We were also very worried because we had entrusted him with the money without signing a document.

Having already "invested" beyond their means into the various projects, the villagers found that the only way they could try to recover their money was to keep working with and giving money to the urban functionary. Villagers felt they had no recourse but to utilize local ethnic social norms, making the agent an extended member of their community. City institutions provided no remedy. Villagers lacked the requisite urban mestizo norms - embodied here by a "signed" document. Instead, they had to try and tie the functionary to the community, increasing his ethnic obligations by providing more contributions. The racial divide between town and country, then, not only isolates natives into weak ethnic enclaves, it enables a feedback loop in which functionaries can fulfill their urban mestizo priorities by increasing community ethnic exploitation.

In this way, urban officials look to use their control over resources to extend their networks of patronage. For instance, a man running for district mayor promised funds for a new school (through a local intermediary) in exchange for villager support in the election. However, the new mayor's proffered school, built by donated village labor, has always remained flooded with stagnant water, never providing any educational benefit. Similarly, regardless of intention, the structure of the Agrarian Bank lending program funneled resources to the locally powerful, resulting in solidifying the traditional authoritarian means of political control rather than increasing popular economic productivity. The political-value of programs in their ability to extend patronage networks far outstrips their use-value in serving the population, such as schools providing education or canals providing water, generally increasing mestizo power while undermining natives' positions.

Overall, with urban and community institutions vesting all power in single individuals, the solicitor system creates the position of local despot to represent indigenous villages. This position must be exclusive and exploitative as the system's clientelism ensures that only the few villagers who create strong connections with urban patronage networks through providing a tractable rural clientele can represent the village. These findings echo the insights of the racial analyses of the 1970 s, with racialization caused by a particular form of political economic integration. Specifically: (1) natives are subjugated as subjects: natives lack citizen rights; they must depend for personhood upon their local despotic patrons whose own citizenship depends on the continued disenfranchisement of their clients; and (2) natives are subjugated as natives: the normal workings of the current system reproduce the colonial system of indirect rule. At the local level, ethnicity enables this racial domination by (1) helping to preclude the village from non-arbitrary institutionalized connections to the larger society, and (2) helping to marshal local resources with which to shore up the clientelist mestizo system.

\section{Cultural Racialization}

Ever-shifting cultural practices enable brokers to make their exclusive connections to urban patronage networks. Even though a wide variety of factors contribute to peoples' racial classification in Latin America, a broad spectrum of scholars and most of the populace agrees that race in Peru, as well as in much of Latin America, generally follows a tripartite hierarchical division, running from whites through mestizos, and down to natives at the bottom (Vargas Llosa, 1990; de la Cadena, 2000; Hale, 2006). Whereas the works on cultural politics emphasize cultural malleability as creating new means of inclusion, in the case of highland Peru culture enables vibrant means of exclusion wherein dominant groups can continuously change the rules of the game to safeguard their privileges.

Tapping into the historically constituted power of mestizaje requires successfully employing multiple aspects of mestizo "cultural capital" (Bourdieu, 1986). Acquiring and maintaining the position of mestizo broker requires employing the further cultural capital specific to urban institutions, or operating according to their mestizo "racial etiquette": the "set of interpretative codes and racial meanings which operate in the interactions of daily life" which confer status and hierarchy in the social system (Omi and Winant, 1994: 60). A major aspect of this etiquette entails 
This is an author-produced, peer-reviewed version of this article. The final, definitive version of this document can be found online at Critical Sociology, published by SAGE. Copyright restrictions may apply. doi: 10.1177/0896920510378768

bolstering urban networks with rural resources. Once brokers deliver, they acquire a relationship with an urban functionary who will then more willingly provide further projects. In this way, brokers achieve the unique resource of institutional approval, the most valuable form of cultural capital. With such capital, brokers can increase their stocks through their more authoritative village control over ever-larger urban originating programs.

To be successful, however, brokers must regularly assert their mestizo credentials at both the community and urban levels, thereby continuously retracing the color line and continuing the state mestizaje project of denigrating the Indian. Only through such regular assertions do they stave off the risk of suffering a similar racialization as the majority of villagers, and do they garner the wages of racial privilege. This is a highly racialized process of cultural distinction as it (1) furthers the construction of natives as anti-modern, (2) predicates mestizo inclusion on continued native subjugation, and (3) vitalizes the cycle of increased native villager exploitation and enhanced mestizo broker authority.

Cultural capital exists in three forms: embodied, objectified, and institutionalized (Bourdieu, 1986). The embodied state largely refers to acquired cultural knowledge, most obviously manifesting itself in Peru through the use of language. Mestizos not only display Spanish fluency and non-Andean accents, but a ready familiarity with a variety of cultural references. As Quechua, spoken by the majority of highland residents, lacks any consistent didactic materials or even a unified spelling scheme, the distinguishing power of language cannot be understated. And further embodied distinctions in comportment, behavior, pastimes, music, festivals, religious practices, education, and employment permeate the Andes. Objectified cultural capital encompasses material objects and is more readily apparent, with indigenous people tending to wear broad-brimmed hats and sandals, while people can distinguish themselves as mestizo through closed-toed shoes, pressed Western clothing, and the full accoutrement of urban living (van den Berghe and Primov, 1977; Weismantel, 1988; Portocarrero, 1993; Lagos, 1994; Degregori, 1995; de la Cadena, 2000). Where most anyone could use their economic capital to quickly acquire the objectified form, only with sufficient embodied cultural capital can people consume these goods in a culturally appropriate way.

Institutionalized cultural capital, however, in its capacity to confer status upon agents, proves the most determinant in the Andean relations of rule. While objectified and embodied capital help brokers gain institutional recognition, enjoying the endorsement of mestizo urban networks bestows tremendous village-level power upon brokers. Indeed, such coveted cultural resources make up the

institutionalized forms of delegation which enable [the village] to concentrate the totality of social capital... in the hands of a single agent or a small group of agents and to mandate this plenipotentiary, charged with plena potestas agendi et loquendi [full power to act and speak], to represent the group, to speak and act in its name (Bourdieu, 1986: 251).

That is, these high concentrations of cultural capital enable brokers to embody the village's social capital - its ability to put people into action.

Mestizo brokers display of all forms of cultural capital at the frequent meetings held in the villages, making these much more sites of racial domination than expressions of "a community's collective vision of its goals" (Warren and Jackson, 2003: 29; cf. Petras and Morley, 1992). Mestizo brokers do not attend most village meetings as the focus tends to be too parochial; for example the Mothers' Club sponsored weekly cleaning of the central square. As one exception, a broker representing the district mayor once charged into a Mothers' Club meeting in a pickup truck any vehicle a rare visitor - loaded with federally funded foodstuffs which he quickly distributed to new mothers. This man therein presented himself as the village's own "outsider," above the tedium of regular meetings, but magnanimously using his wherewithal for the good of the village. While the mothers would have received these goods regardless, by grafting his identity onto this mestizo program he validates the authoritarian idea that the few people like him, by knowing the mestizo city and the native village, can best decide and deliver what is best for the community, while actually doing nothing at all.

Rather than providing enlightened leadership, though, brokers do more to obfuscate the mestizo urban core, making it seem impenetrable and thereby making themselves appear invaluable to the village. The few meetings they do attend are central to community affairs. Sometimes brokers make great displays of condescending to come to the 
This is an author-produced, peer-reviewed version of this article. The final, definitive version of this document can be found online at Critical Sociology, published by SAGE. Copyright restrictions may apply. doi: 10.1177/0896920510378768

meetings which take away from their more crucial affairs in the city. One man once arrived over the gouged roads in a taxi, therein displaying a time poor but money rich image which dramatically contrasts villagers' long walks to their small fields.

When brokers attend, they dominate. As discussed above, mestizo brokers tend to hold the most important local offices because of their privileged connections to the city. But even when they have no official authority, they assume central roles at meetings and do most of the talking. Their self-presentation exudes mestizo objectified cultural capital: tight haircuts, fancy watches, and trim clothes while eschewing the broad-brimmed hats, patched clothes, and retread tire sandals of the majority. This starkly demarcates mestizos as "better," as able to function in the outside world in a matter-of-fact way alien to villagers, thereby vesting local mestizos with seemingly inherent authority.

But their actions at these meetings do the most to exacerbate native alienation from the urban core. For example, a man who held no elected position led one meeting and dominated it through longwinded "explanations" about the current legal standing of the community and how it related to the village's history. He shook a dog-eared stack of documents as "papers speak, because with the mouth sometimes we augment speech," explaining what he had found in a search for village records:

A constancy notice of search for the property title of the Peasant Community of Huaytabamba, that this says is negative. A notice of search for the document of sale of the hacienda Huaytabamba in the name of Héctor A.V., Dolores G.B., that is negative. A copy of the formula certificate of tax payments to the Ministry of Haciendas and Commerce National Superintendent of Contributions and Registry of the Contributions of Taxes to the Rent of Mobile Capital; and they said that the Peasant Community of Huaytabamba does not appear at the PETT, that is the Special Project for the Titling of Lands.

His mix of legalese and baroque-sounding institutions to which he "obviously" enjoyed ready access amounted to a different language, even though he spoke this in Quechua. His explanation was designed not only to confuse and intimidate but also to demonstrate his unassailable superiority in all matters urban.

These political-cultural distinctions also show themselves in comportment. At meetings, for instance, most villagers engage in a "high context" manner, acknowledging the importance of social connections through thanking a list of people before they make a statement. In contrast, mestizo brokers and urban agents tend to skip these aspects and immediately speak on specific issues. Similarly, villagers generally engage with urban functionaries through a paternalist dialogue, villager obsequiousness matched by urban condescension, including a pervasive use of childish names like "my little son" or "little father." This alone reinforces the cultural gap, insisting that these individuals will never engage openly, but only as people on different levels of the hierarchy. In contrast, brokers tend to engage in easy fraternal dialogue with functionaries, alienating villagers by overtly displaying an affinity unavailable to them.

\section{Institutionalized Cultural Capital}

While community meetings provide a local venue for distinction and domination, the authoritarian racialization of resources primarily emanates from urban institutions themselves. Acquiring the power of institutionalized cultural capital generally requires entering into a reciprocal relationship with an urban functionary. Once such a relationship is demonstrated, particularly through the delivery of projects and resources, institutionalized cultural capital makes brokers increasingly unassailable in their local positions, enabling greater impunity over larger village sums.

The racial etiquette of these institutions creates enormous cultural barriers to entry, with the result of screening out the majority and selecting a small minority. To illustrate this, I contrast the interactions I had with one urban institution to the relationship a village broker developed with another. While my attempts to create an institutional link with CARE-Peru only resulted in humiliation for myself and the non-broker villager with whom I worked, the relationship between a village broker and another functionary blossomed to the point of establishing their own organization, DICCPUM, through which they were able to dramatically increase villager exploitation and spread their "services" to other geographic areas. 
A villager and I approached the local office of CARE-Peru to solicit funds (\$400) for the cement and roofing materials of a compost producing facility that the villager had designed. I naively believed that the villager provided sufficient "authenticity" to show this was a productive grassroots project, and that I brought professionalism in the form of a clearly articulated plan, including a printed proposal with a timetable and budget, detailed drawings, and a "compost committee" notarized book of minutes.

Two major results emerged from our meeting. First, my village colleague did not want to enter the CARE building. While it was an imposing structure reflecting foreign wealth and power, only when we entered and the CARE functionary began systematically humiliating my compatriot did I understand his reluctance. The CARE official treated the villager like a misbehaving child, dismissing his ideas, knowledge, and presence as utterly trivial. The other result was that the official extracted a tribute from me in the form of my "volunteering" for another of his projects on the promise of engaging our plan in the future - which he never did. No one ever met me when I volunteered, turning my efforts into a wasted, uncomfortable day-long trip and another humiliation; but it enhanced the agent's prestige within his network by showing he could manipulate a gringo (an inescapably marked category of wealth and power) to serve his whims.

Humiliating the villager was clearly a regular practice, displaying power but also serving as a test and a potential rite of passage. Racism, however, provided its base, with the official denigrating the villager and all he represented as irredeemable. While both the villager and I hoped to get in his good graces by acting obsequiously, in retrospect, the agent employed a highly culturally bound way to seek reciprocity for entrée into his extended network. I felt we asked for a fairly trivial sum that promised an easily reproducible way to enhance the productivity of the "poorest of the poor" (an aspect of CARE's mission). My meritocratic gringo proposal found no purchase, nor did the villager's local knowledge. Instead, we were supposed to offer a meaningful way to enhance this agent's network, part of which entailed proving we could force him to fulfill his promise.

Under horrible conditions, the villager was supposed to prove he was not a "degraded Indian" but someone who could speak the manager's own cultural "language" and deliver for the network by maintaining a regular but uneven reciprocal relationship. While I faced no mortifying cultural test, I would have had to have entered into a relation in which my continual work for the agent would force his compliance. As with the police running from the field in the Huaytabamba land dispute, enforcement mechanisms mostly remain informal and are based on an understanding about the inherent superiority of mestizo urban culture and the undeservingness of rural highland society. Not only did we lack the right cultural knowledge and economic leverage to access resources, we quickly became contemptible and easily exploited subjects.

To some level, CARE had to screen their supplicants or risk its funds being used to enhance competing networks. For instance, as villagers became more desperate and lacking any control over Cattle Reactivation, they acquired a soil conservation project from a different service provider. These funds similarly disappeared after villagers sent them to the Reactivation broker and functionary in Lima who said they "just lacked a few signatures" and needed money for the final "processing" [gestionando]. With the normalcy of such extortion, then, personal relationships best guarantee the "proper" use of funds. But these funds likewise are the best resource for solidifying such relationships, strongly reinforcing the personalism at the core of resource provision. And, as shown here, mestizo racial etiquette becomes shorthand for screening the individuals who understand these rules of the game.

In contrast to my stymied attempts to solicit CARE, the tight relationships village brokers enjoyed with their partner at SierraCentroSur, described above, demonstrate that adroit mestizo cultural competence in the urban sphere results in exploitative authoritarianism in the community. The unique background of the leading broker helps explain how he could achieve such ties. Early in his life, this broker, Damian, became the baptismal godson of the childless daughter of the owner of the hacienda that later became the community. Villagers generally concur with his story that she informally adopted him, taking him to the jungle town of San Francisco where she had a teaching appointment. There she provided him with a formal education, generally unheard of for villagers his age and a giant step from his illiterate father and uncles.

Close ties to this woman and the hacienda family in general helped uniquely socialize him into mestizo ways, granting him great facility with the workings of urban institutions. He claims that in 1968, at age ten, he was the most qualified to help the district judge demarcate the lands the hacendado was selling to the peasants in fear of the brewing land reform. He further claims he successfully garnered lopsided rulings for his father and other favored 
family members. While his closest family members dismiss his claims of degrees from the university in Ayacucho and a local technical school, the tight relationship with his privileged godmother granted him unmatched technical and cultural skills for catering to mestizo racial etiquette. Given sufficient will (for which his socialization arguably primed him), he was uniquely positioned to create lasting and lucrative relations with urban officials - some of whom emanated from his godmother's family. And villagers readily acknowledged the esoteric skill set uniquely possessed by brokers which allowed them to access urban institutions, regularly saying these men "know how to enter the institutions," or "know how to talk to the engineers," or that they have a godfather in an agency that enables them unique privileges.

Damian, then, was uniquely positioned to develop a mutually beneficial relationship with his contact at SierraCentroSur, including a paid position for himself, as long as he continued to bring village funds back into the relationship. In the building of a village reservoir, for instance, Damian successfully siphoned funds earmarked for village labor costs. Villagers complained that the smallness of the reservoir limited its agricultural use, whereas the daily wages would have provided a welcome relief, which was most likely the populist government's main intention. Thus, providing a tangible resource helped solidify the broker-agent relations and the broker's authoritarian and exploitative local power, with these funds remaining in the hands of the broker and his urban partner.

Through skimming resources from such projects, Damian and his partner formed and financed their own agency, DICCPUM (Integrated Development for Peasant Communities and Marginal Urban Areas) through which they could launch more such projects, set up operations in Lima, and expand their geographic and exploitative scope. In particular, through DICCPUM they launched the Cattle Reactivation project. As villagers described it, "bringing us these works they were going to go to Lima, this was definitely their intention." That is, rather than focused on building village infrastructure, the functionary and Damian - this witness's brother - brought tangible if ersatz results through small project in order to establish DICCPUM in Lima. And from this less accountable position they could launch the Reactivation and eventually strip villagers of all their resources.

Damian bragged to me that he had worked throughout Ayacucho and three other departments and had various women throughout the country. As one man bitterly recalled, "He kept us dizzy with his different plans.... I went to Lima and I found him living in a hotel, a good hotel, eating always in restaurants.... and from that moment we started distrusting and he disappeared and we knew had been fooled." In all, the institutional cultural capital achieved through catering to urban mestizo demands for a compliant rural clientele created a circular and cumulative relationship wherein the funds siphoned from the community intensified broker authority and the ability to take greater resources until villagers paid astronomical amounts for a project, Reactivation, that provided no results at all.

Together, the institutional forms and the cultural practices provide the cumulative and circular causality pushing for continued native subordination. The distinctly "indigenous" governing apparatus militates for rural authoritarianism while culture delineates between the privileged and the exploited, the legitimate from the incompetent. Bringing rural resources to support urban patronage networks grants brokers despotic control over ever-larger programs while providing them with unmatchable institutionalized cultural capital. This enhanced authority allows for the greater extraction of village resources and a spiraling cycle that rigidifies the durable inequalities between mestizos and natives.

\section{Naturalization}

While my description of these practices of distinction may make them appear to require constant, deliberate actions, they are actually highly naturalized as part of normal day-to-day routines, making this racism both pervasive and incredibly difficult to overcome. Urban functionaries maintain their jobs by controlling limited resources. They need personal relationships to guarantee the funds will be used appropriately, while at the same time they need the funds to guarantee these relationships. Given the historical process of state mestizaje, these agents, in effect, are safeguarding their group's monopoly control over these positions, practicing what Weber (1968 [1922]: 43) calls social "closure," or, looking more at hierarchy, what Tilly (1998) terms "opportunity hoarding." While such practices implicitly equate to exploitation, their repeated use also reveals their culturally entrenched nature as the "cheapest," default way of operating. The outward manifestation is that natives are seen as largely incapable of handling resources; but the cause lies in vested interests seeking to maintain the status quo. 
Rather than going out of their way to exclude the majority, urban agents do so simply by falling back on longstanding - though ever-morphing - practices. In such, as with much racialized resource distribution throughout the world, urban officials simply need to provide the resources to the individuals they are "naturally" predisposed to. And because this tends to occur at a subconscious level, basing resource distribution on simple cultural affinity has been shown to powerfully perpetuate racial inequality across multiple arenas, such as job hiring in the US (Neckerman and Kirschenman, 1991; Brief et al., 1995; Pager and Quillian, 2005) and in Peru (MacIsaac and Patrinos, 1995). This is readily visible in rural Peru. Villagers regularly defer to the "natural" local leaders [dirigentes] and urban agents deal almost exclusively with the same group. Doing otherwise would run against commonsense.

This deep racialization of urban institutions has major self-reinforcing mechanisms in which, barring major structural changes, the brokers do represent the village's best immediate chance at acquiring external resources despite the standard practices of peculation. Brokers did bring some limited positive results through their projects. Even though villagers were supposed to receive all of the Agrarian Bank loans, they still received half, amounting to unprecedented sums. While most people sold the animals they bought with these loans in order to finance the Cattle Reactivation, successful brokers can deliver tangible results well beyond the capacity of most villagers. Similarly, while Damian ended up with all the money earmarked for labor, he did provide a reservoir, however small and prone to failure. And another broker did acquire the new primary school; the lack of accountability in the system did not have to result in it being permanently flooded.

Just as these few individual mestizos successfully bring resources to the community, however faulty, brokerage by non-mestizos - people unwilling or unable to conform to mestizo racial etiquette - generally proves fruitless. One villager, for instance, pointed to the small garden at the primary school as the apex of his presidential accomplishments. The election of such non-elites amounts more to a protest of broker corruption rather than any kind of meaningful alternative. The populace voiced two general critiques of village leadership, accusing officials of either lazy incompetence or of corruption. The former was generally applied to the non-brokers who clearly lacked sufficient connections to serve the village. Traditional leaders, however, were regularly accused of corruption and sometimes even threatened with official complaints. However, these men weathered such criticism and remained the key representatives of the community. As one NGO worker complained to me, "those who lead are not the ones who rule," meaning that brokers worked in the name of the village regardless of office title, and that the community provided little restraint over these true power holders.

And continued villager support must be understood within the context of impoverished rural Peru. Amid such scarcity, villagers welcome all projects as potential opportunities. That most projects, regardless of who brokers them, sit half-finished or in disrepair provides grist for complaints, but also shapes expectations about normal outcomes and the complications behind finishing even the simplest project. An earthquake in Pakistan prevented ADRA from delivering USAID donated foodstuffs. CARE promised, and failed to deliver, a small roof once villagers built the adobe walls of a guinea pig farm because anti-CARE coca farmer protests in the jungle caused a complete institutional overhaul. In this environment, brokers are at least tacitly forgiven for their total failures - a half-built chapel, a treeless arboretum - while their limited successes - a leaky reservoir, faulty outhouses - appear unmatchable.

Further, exploitation, particularly in the form of unremunerated labor, is an inbuilt aspect of community life. The faena system at the heart of local ethnic identity primes villagers to provide free labor. The hope is that unpaid labor will bear future fruit. But this only happens infrequently and, perhaps ironically, mostly with broker sponsored projects (though not with most of their projects). An ethnically bound "developmentalist" ideology that villagers must work for the good of the community provides the faith behind such labor donation. Brokers providing a range of projects, a few of which have some limited quality, enable them ever-greater authority up to the point of fantastic failures like Reactivation.

At this point, villagers can react severely, particularly against the institution that enabled their exploitation. After Reactivation failed, villagers "lost all faith in the [community] authorities and then came the destruction; the community become totally disorganized; they would not even give a little bit so the [new] authorities couldn't do anything." But this also helps the brokers who generally have gained tremendously through such Ponzi schemes. Instead of reforming community government to achieve some justice against rapacious intermediaries, villagers end up dismantling what amounts to their primary vehicle for ethnic mobilization. The entrenchment of community 
This is an author-produced, peer-reviewed version of this article. The final, definitive version of this document can be found online at Critical Sociology, published by SAGE. Copyright restrictions may apply. doi: 10.1177/0896920510378768

government in the structures of despotic resource procurement thereby forces villagers to choose between a government which is exploitative or ineffectual. But because the community represents the best chance to secure external resources, villagers eventually return to it. And villagers end up supporting the same brokers or their cronies as they, with their considerable institutional cultural capital, are best positioned to remobilize the community.

Finally, "culturalist" racist rationalizations present the unequal social relations as "normal." Specifically, this ideology blames the indigenous population for its own poverty, naturalized as individual failures to compete successfully in the larger mestizo culture (cf. de la Cadena, 2000). Extorting rural resources is not seen as exploitation but simply as greater competitive success. "Look, anybody can walk into the [urban] agencies" one broker regularly intoned to me, meaning that resources are available to any individual who has the courage and "character" to ask. Individuals who successfully access state resources are free to use them as a reward for their hard work. Others "legitimately" miss out on the resources because they lost a fair competition.

Village elite similarly expressed "culturalist" prejudicial attitudes purporting to explain the overall situation of continued inequality. A man I regarded as very thoughtful and not opportunistic explained to me that "the problem we have here is a lack of culture," elaborating this to mean that "the people will not educate themselves.", Many others also regularly stressed the impoverished destiny people faced by not prioritizing education but instead spending their money on their animals. More frequently, elites relied on tropes about individual characteristics, declaring that the "campesinos" "are not ambitious," or "are very conformista," or "do not put in the necessary work, and they lack knowledge and experience," or more simply they "are accustomed to handouts and get lazier." The most powerful trope, however, consisted of pointing to all the failed projects in the village which the elite were good enough to broker but which the villagers could not maintain.

In sum, with these practices deep-seated in local culture, racial inequality persists through people at all levels going about their normal business, rather than through people acting from malicious bigotry. Urban officials entrust resources to the broker with whom they share a natural empathy. Intermediaries do what a natural leader needs to do in order to safeguard future resources for the community. Villagers, facing a scarcity in which ersatz projects represent wealth, support brokers politically and with labor and funds. And culturalist racism provides the rationalizations through which mestizo "power secures its dominance by seeming not to be anything in particular" (Lipsitz, 1995, quoting Dyer, 1988).

\section{Conclusion}

Over ten years ago, Weismantel and Eisenman (1998: 122) urged scholars to return racial analyses to indigenous Latin America as, among other reasons, the predominating ethnic analysis "works to remove from view the historical specificity of oppression." Since then, very little headway has been made, particularly in identifying the sources of durable racial inequalities. In this article, I have articulated the primary elements of the Peruvian racialized social structure that militate for continued indigenous subordination. Specifically, a system of indirect rule institutionally segregates natives into ethnic enclaves ruled despotically by mestizo intermediaries whose own privileged position depends on facilitating native exploitation. The institutions linking native villages to the city facilitate local despotic rule. Predicating resource access on mestizo cultural know-how ensures that only a few villagers with mestizo priorities will ever serve this role. And the clientelistic manner of resource allocation makes the system particularly exploitative, with rural resources primarily bolstering urban patronage networks. Because it is embodied by mestizo authoritarian intermediaries, native "success" results in strengthening the color line, increasing the power of local despots and their ability to exploit their indigenous wards.

Empirically, this manifests itself in the two intertwining questions of how brokers have so much power and why villagers continually offer support. That these questions partially answer each other - villager backing makes brokers powerful while broker power entices villager support - helps explain the durability of racial inequalities. But power emanates from the urban core. Brokers have so much power because urban institutions need a single individual who will locally oversee projects in such a way as to invigorate their urban clientelist network. Urban agents need a personal relationship with brokers to safeguard the appropriate use of funds, and funds best fortify these relations. As brokers build their urban connections, then, their despotic ability and motivation to exploit the village only increase. But, overall, since urban officials largely do not see anything intrinsically wrong with the system, these dynamics mostly serve to keep everyone, particularly natives, in their place. 
Similarly, since brokers are vested with so much urban power, they represent villagers' best chances to access resources, even with exploitation endemic. Poor infrastructure and failed projects make up the legacy of indigenous rural Peru. The rare ability to initially access scarce external resources, coupled with a few limited successes, maintains community support. Villagers readily recognize the costs and risks of project acquisition. But they are almost always eager to face these because of their impoverished situations. Rather than making cold cost-benefit analyses, villagers are instead desperately seeking external resources to make their labor productive, just as in the most traditional forms of exploitation. The system can spiral up to spectacularly extortive actions, like the Reactivation; but these are made up of the many small exploitive events through which communities acquire their few poor resources - the leaky reservoirs, dirty "potable" water systems, non-private privies, and collapsing potato barns. Villagers will temporarily withdraw from the community system, the closest manifestation of the engine of their exploitation; but their lack of options will slowly draw them back.

Through illustrating these relations, I have aimed to show that the regeneration of the position of authoritarian intermediary, rather than any individual broker, is responsible for perpetuating native subordination. Instead of a choice between authoritarian and non-authoritarian village representation, potential community leaders face the conundrum of local despotism or ineffectiveness, while villagers face the choice between exploitative and inept leadership. Even when natives have come to occupy this position, as Hale (2004) shows for Guatemala, they are forced to make hard choices between becoming an "authorized Indian" revitalizing the racist system by giving it a native face or being cast as self-marginalizing and even terrorists. The position matters much more than who occupies it.

My work supplies a general framework generating many questions for future research. In particular, new issues arise for works on race and ethnicity. Suggesting a route out of the debate between racial or ethnic predominance, my work indicates that race and ethnicity operate simultaneously in the Andes. Racial subordination occurs through ethnic fracturing; and ethnic struggles operate against racial domination. This creates opportunities for work on ethnicity to confront the "historical specificity of oppression" and explore how ethnic based movements are both constrained by and challenge racialized rule. Similarly, where critical race theory has been criticized for overly dismissing the impact of identity based collective group behavior (e.g., Cornell and Hartmann, 1998), my work suggests a way to better incorporate ethnicity without lessening the weight of racial domination. Bringing race and ethnicity together, future work can address questions such as: how and to what extent do ethnically based struggles challenge racialized rule? What are the processes through which consent is granted at the local level? What variation in the scope and character of exploitation does the system permit? How can extreme forms of exploitation be mitigated without large-scale structural change? In this way, future studies can also investigate the interrelation of existing racialized social structures with the more recent neoliberal and multicultural trends which come after the events I detail here (cf. Hale, 2004; 2006; Postero, 2006). How do these challenge, fortify, and otherwise change racialized rule?

Similar to work on other regions (Kim, 2006) my research also helps expand the purview of critical race theory to shed light on tripartite racial systems and indigenous populations in the Americas. While some of the first peoples racialized through the colonial project, and thereby playing a major role in the development of critical race theory, American natives so far remain outside the core of race studies. While my research offers a basic framework, more comparative research on indigenous experiences in other countries promises to add needed complexity (cf. Mallon, 1992). Similarly, advancing research into the tenuous dynamics maintaining intermediary racial groups should prove useful to a variety of venues, including the US and areas ruled by numerical minorities (Bonilla-Silva and Glover, 2004; Chua, 2004). By broadening the applicability of racial studies we can move away from studying "historicallyspecific racisms" unique to their own locale and era (Hall, 1980: 336 cited in Bonilla-Silva, 1997: 475). Instead, we can work towards understanding truly global racial dynamics and how dominant groups garner racial privileges on a world scale.

\section{Acknowledgements:}

Research was partially funded by a Fulbright-IIE Fellowship. I want to thank everyone in Peru who opened up their hearts and lives to me. Edilberto Jimenez Quispe proved an invaluable research assistant and teacher. Thanks to Gay Seidman, Jane Collins, Karl Zimmerer, Steve Patrick, Don Winiecki, Michael Blain, Mark Harvey, Susie Mannon, Brian Dill, Jim Scarritt, and two anonymous reviewers for insightful comments on earlier drafts. And thanks most of all to Jill Lawley and Fred Scarritt for their life support. All errors, of course, are solely mine. 
Figure 1: the Peruvian Racialized Social Structure

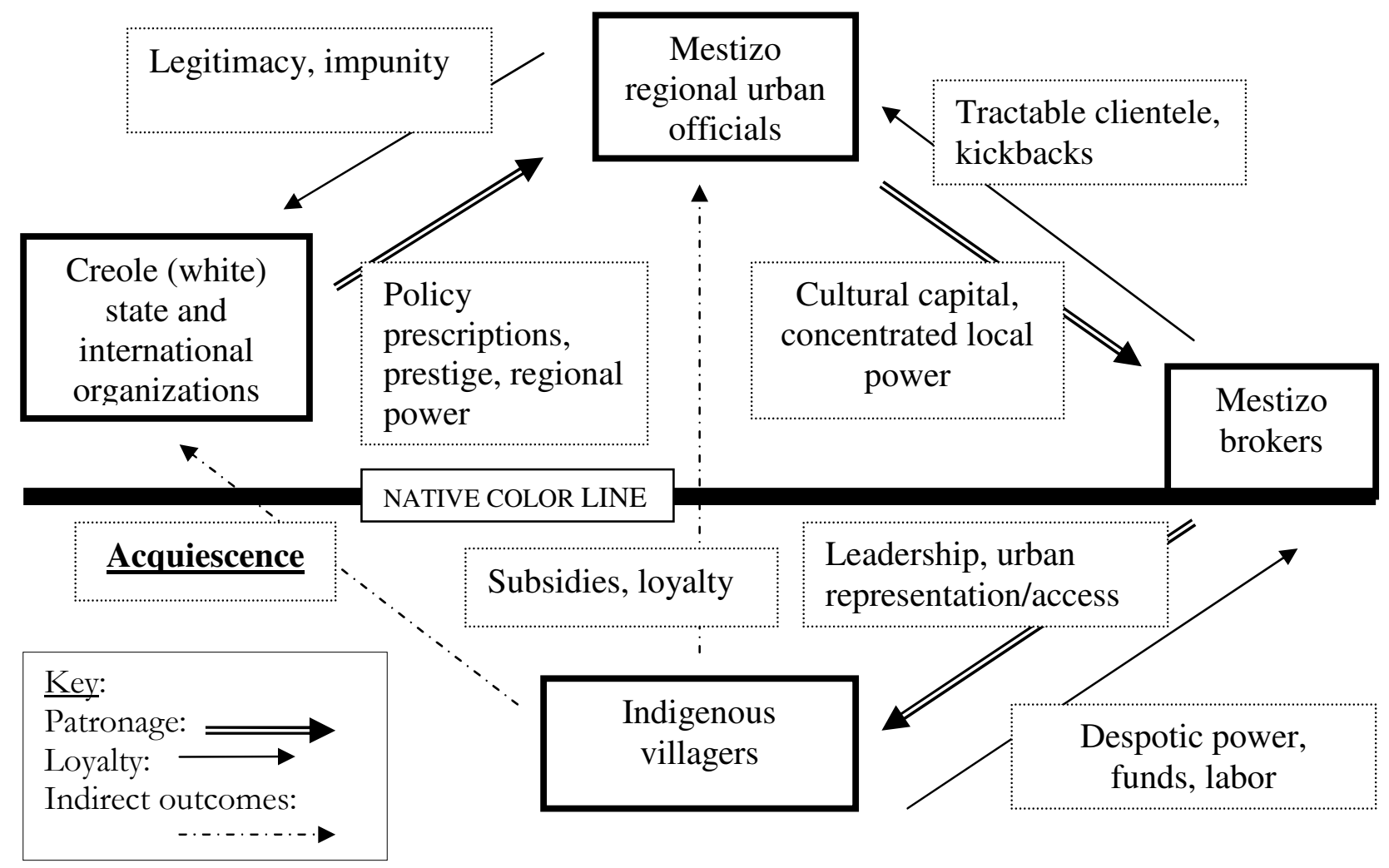

Figure 2: the Exploitation-Authority Cycle

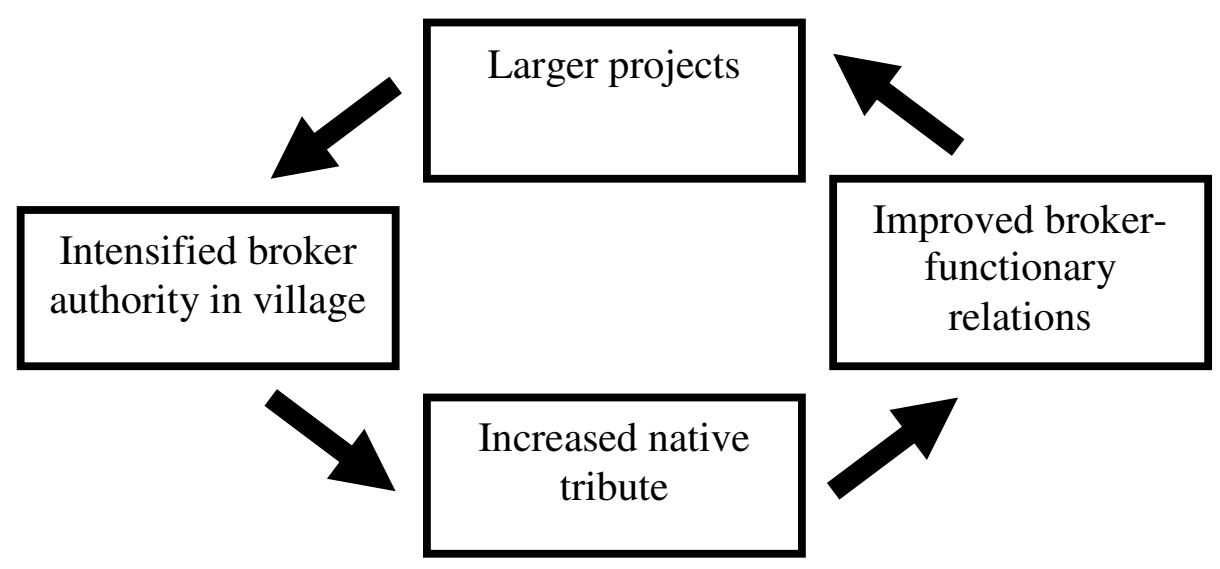


This is an author-produced, peer-reviewed version of this article. The final, definitive version of this document can be found online at Critical Sociology, published by SAGE. Copyright restrictions may apply. doi: 10.1177/0896920510378768

\section{Notes}

${ }^{1}$ These numbers reflect the relatively arbitrary figure of US $\$ 1$ per person per day, meaning that poverty shapes the reality of well more than twothirds of the native population (cf. Pogge, 2001).

${ }^{2}$ Mainstream analyses of patronage in governments across the globe (e.g., "Earmarks" in the US) explain that competition between patronage sources forestall the excesses witnessed in earlier eras of machine politics, a restraint the highland solicitor system mostly lacks (Roniger, 1994).

${ }^{3}$ In Spanish, "cultura" can translate directly to "culture" or mean something closer to "education," as the speaker intends it here. But such an understanding of education entails significant assimilationist aspects, continuing the notion that villagers are to blame for their own situation because they do not want to "better" themselves by conforming to the urban mestizo culture.

\section{References}

Albó, X. (1994) Ethnic Violence: the Case of Bolivia. K. Rupesinghe (ed.) The Culture of Violence United Nations University Press.

Allen, C. (1988) The Hold Life Has. Smithsonian Institute: Washington, DC.

Ansell, A. (2006) Casting a Blind Eye. Critical Sociology 32(2-3)333-56.

Bonilla-Silva, E. (1997) Rethinking Racism. American Sociological Review 62(3):465-480.

Bonilla-Silva, E. (1999) The Essential Social Fact of Race. American Sociological Review 64(6):899-906.

Bonilla-Silva, E. (2001) White Supremacy and Racism in the Post-civil Rights Era. Lynne Rienner: Boulder.

Bonilla-Silva, E and Glover, K. (2004) 'We are all Americans!' The Latin Americanization of Race Relations in the USA. M. Krysan and A. Lewis (eds.) The Changing Terrain of Race and Ethnicity, pp. 204-19. Russell Sage: New York.

Bourdieu, P. (1996) The Forms of Capital. J. Richardson (ed.) Handbook of Theory and Research for the Sociology of Education, pp. 241-58. Greenwood Press: New York.

Bourdieu, P and Wacquant, L. (1999) On the Cunning of Imperialist Reason. Theory, Culture and Society 16(1):4158.

Bourricaud, F. (1975) Indian, Mestizo, and Cholo as Symbols of the Peruvian Stratification System. N. Glazer, D. Moynihan and C. Schelling (eds.) Ethnicity: Theory and experience, pp. 350-87. Harvard University Press: Cambridge.

Brief, A., Buttram, R., Elliott, J., Reizenstein, R., and McCline, R. (1995) Releasing the Beast: A Study of Compliance with Orders to Use Race as a Selection Criterion. Journal of Social Issues. 51:177-193.

Chua, A. (2000) The Paradox of Free Market Democracy. Harvard International Law Journal. 41(2):287-379.

Collins, P. (1996) Black Feminist Thought. Routledge: New York.

Cornell, S. and Hartmann, D. (1998) Ethnicity and Race. Pine Forge: Thousand Oaks.

Cotler, J. (1968) La Mecánica de la Dominación Interna y del Cambo Social en el Perú. Peru Problema 1:153-197. IEP: Lima.

De la Cadena, M. (2000) Indigenous Mestizos. Duke University Press: Durham.

Degregori, C. (1995) El Estudio del Otro. J. Cotler (ed.) Peru 1964-1994, pp. 303-32. IEP: Lima.

Dyer, R. (1988) White. Screen 29(44):115-9. 
This is an author-produced, peer-reviewed version of this article. The final, definitive version of this document can be found online at Critical Sociology, published by SAGE. Copyright restrictions may apply. doi: 10.1177/0896920510378768

Flores-Galindo, A. (1987) Buscando un Inca. IAA: Lima.

Fuenzalida, F. (1970) Poder, Raza y Etnía en el Perú Contemporáneo. Perú Problema 4:15-87. IEP: Lima.

Goldberg, D. (2002) The Racial State. Blackwell Publishers: Malden, MA.

Goldberg, D. (2009) The Threat of Race. Wiley-Blackwell: Malden, MA.

Gonzales de Olarte, E. (1998) El Neoliberalismo a la Peruana. IEP: Lima.

Gose, P. (1994) Embodied Violence. D. Poole (ed.) Unruly Order, pp. 165-98. Westview: Boulder.

Gould, J. (1998) To Die in this Way. Duke University Press: Durham.

Grandin, G. (2000) The Blood of Guatemala. Duke University Press: Durham.

Hale, C. (1997) Cultural Politics of Identity in Latin America. Annual Review of Anthropology 26:567-90.

Hale, C. (2004) Rethinking Indigenous Politics in the Era of the 'Indio Permitido'. NACLA Report on the Americas $38(2): 16-22$.

Hale, C. (2006) Más que un Indio. School of American Research: Santa Fe.

Hall, S. (1980) Race Articulation and Socieities Structured in Dominance. Sociological Theories: Race and Colonialism, pp. 305-45. UNESCO: Paris.

Holdaway, S. (1997) Some Recent Approaches to the Study of Race in Criminological Research. British Journal of Criminology 37(3):383-400.

Isbell, B. (1978) To Defend Ourselves: Ecology and Ritual in an Andean Village. University of Texas Press: Austin.

Kelly, J. (1998) 'Experiences with the White Man’ Black Student Narratives. Canadian Ethnic Studies 30(2):95113.

Kim, N. (2006) 'Seoul-America' on America's 'Soul': South Koreans and Korean Immigrants Navigate Global White Racial Ideology. Critical Sociology 32(2-3)381-401

Klarén, P. (2000) Peru: Society and Nationhood in the Andes. Oxford University Press: New York.

Lagos, M. (1994) Autonomy and Power: the Dynamics of Class and Culture in Rural Bolivia. University of Pennsylvania Press: Philadelphia.

Lipsitz, G. (1995) The Possessive Investment in Whiteness. American Quarterly 47(3):369-87.

Loveman, M. (1999) Is 'Race' Essential? American Sociological Review 64(6):891-98.

MacIsaac, D. and Patrinos, H. (1995) Labor Market Discrimination against Indigenous People in Peru. Journal of Development Studies 32(2):218-33.

Mallon, F. (1992) Indian Communities, Political Cultures, and the State in Latin America, 1780-1990. Journal of Latin American Studies 24(Suppl):35-53.

Mallon, F. (1995) Peasant and Nation. University of California Press: Berkeley.

Mamdani, M. (1996) Citizen and Subject. Princeton University Press: Princeton.

Mamdani, M. (1998) The Politics of Civil Society and Ethnicity. Political Power and Social Theory 12:221-233. 
This is an author-produced, peer-reviewed version of this article. The final, definitive version of this document can be found online at Critical Sociology, published by SAGE. Copyright restrictions may apply. doi: 10.1177/0896920510378768

Matos Mar, J. (1969) Micro-Región y Pluralismo. IEP: Lima.

Mills, C. (1998) Blackness Visible. Cornell: Ithaca.

Morner, M. (1966) Race Mixture in the History of Latin America. Little Brown: Boston.

Neckerman, K. and Kirschenman, J. (1991) 'We'd Love to Hire Them But'. Social Problems 38(4):433-47.

Omi, M. and Winant, H. (1994) Racial Formation in the United States, 2nd ed. Routledge: New York.

Otero, G. (2003) The 'Indian Question' in Latin America. Latin American Research Review 38(1):248-66.

Pager, D. and Lincoln, Q. (2005) Walking the Talk? What Employers Say Versus What They Do. American Sociological Review 70:355-380.

Petras, J. and Morley, M. (1992) Latin America in the Time of Cholera. Routledge: New York.

Pogge, T. (2001) Global Poverty. Public Affairs Report 42(2):14-6.

Portocarrero, G. (1993) Castigo sin Culpa, Culpa sin Castigo. Racismo y Mestisaje, pp. 33-96 SUR: Lima.

Postero, N. (2004) Articulations and Fragmentations: Indigenous Politics in Bolivia. N. Postero and L. Zamasc (eds.) The Struggle for Inidigenous Rights in Latin America. Sussex Academic Press: Portland.

Postero, N. (2007) Now We Are Citizens. Stanford University Press: Stanford.

Quijano, A. (1965) El Movimiento Campesino en el Perú y sus Líderes. America Latina III(4):43-64.

Rappaport, J. (1994) Cumbe Reborn. Chicago University Press: Chicago.

Rappaport, J. (2005) Intercultural Utopias. Duke University Press: Durham.

Roniger, L. and Güneş-Ayata, A. (1994) Democracy, Clientelism, and Civil Society. L. Rienner: Boulder.

Rostow, W. (1960) The stages of Economic Growth. Cambridge University Press: Cambridge.

Rotta Castilla, S and Narvarte Olivares, L. (2006) Peru. Transparency International. Global Corruption Report 2006.

Rubin, J. (1997) Decentering the Regime. Duke University Press: Durham.

Sawyer, S. (2004) Crude Chronicles. Duke University Press: Durham.

Thurner, M. (1997) Atusparia and Cáceres. Hispanic American Historical Review 77(3):409-21.

Tilly, C. (1998) Durable inequality. University of California Press: Berkeley.

Transparency International. (2006) Global Corruption Report 2006. Transparency International.

Urrutia, J. (1992) Comunidades Campesinas y Antropología: Historia de un Amor (Casi) Eterno. Debate Agrario 14:1-16.

Van den Berghe, P. and Primov, G. (1977) Inequality in the Peruvian Andes. University of Missouri Press: Columbia.

Vargas Llosa, M. (1990) Questions of Conquest. Harper's Magazine December:45-53. 
This is an author-produced, peer-reviewed version of this article. The final, definitive version of this document can be found online at Critical Sociology, published by SAGE. Copyright restrictions may apply. doi: 10.1177/0896920510378768

Vasconcelos, J. (1979 [1925]) La Raza Cósmica. California State University: Los Angeles.

Wade, P. (1997) Race and Ethnicity in Latin America. Pluto Press: Chicago.

Warren, K. (1992) Transforming Memories and Histories. A. Stepan (ed.) Americas: new Interpretive Essays edited by. Oxford University Press: New York.

Warren, K. and Jackson, J. (2003) Indigenous Movements, Self-representation, and the State in Latin America. University of Texas Press: Austin.

Weber, M. (1968 [1922]) Economy and society. Bedminster Press: New York.

Weismantel, M. (1988) Food, Gender, and Poverty in the Ecuadorian Andes. University of Pennsylvania Press: Philadelphia.

Weismantel, M. and Eisenman, S. (1998) Race in the Andes: Global Movements and Popular Ontologies. Bulletin of Latin American Research 17(2):121-142.

Winant, H. (2001) The World is a Ghetto. Basic Books: New York.

Wolf, E. (1982) Europe and the people without history. University of California Press: Berkeley.

Wolpe, H. (1980) Articulation of Modes of Production, Routledge: New York.

World Bank. (2005) Indigenous Peoples, Poverty and Human Development in Latin America: 1994-2004. World Bank: Washington, DC.

Young, C. (1976) The Politics of Cultural Pluralism. University of Wisconsin Press: Madison.

\section{For correspondence:}

Department of Sociology, Boise State University, 1910 University Drive, Boise, Idaho 83725. Email: arthurscarritt@boisestate.edu 